\title{
Drynaria quercifolia suppresses paracetamol-induced hepatotoxicity in mice by inducing Nrf-2
}

\author{
Chatterjee $\mathrm{S}^{1}$, Bhattacharya $\mathrm{S}^{1}$, Choudhury $\mathrm{PR}^{2}$, Rahaman $\mathrm{A}^{1}$, Sarkar $\mathrm{A}^{1}$, Talukdar $\mathrm{AD}^{2}$, \\ Mandal DP ${ }^{1}$, Bhattacharjee $\mathrm{S}^{1}$
}

Department of Zoology, West Bengal State University, Berunanpukuria, Malikapur, Barasat, Kolkata, West Bengal, India. shamee.zoology@wbsu.ac.in

\begin{abstract}
Paracetamol is a popular and safe drug preferred by victims of pain or pyrexia; however, its overdose or abuse is a growing concern worldwide. Here the hepatoprotective effect of an ethnomedicinal plant Drynaria quercifolia against paracetamol-induced toxicity in murine model is demonstrated. This fern, native to tropical countries including the Northeast India, is used by local tribes to treat inflammatory conditions. Paracetamol $500 \mathrm{mg} / \mathrm{kg}$ body weight was orally administered on alternate days for a period of 21days to mimic a chronic overdose. Drynaria quercifolia acetone extract (DQA) treatment interspaced with paracetamol significantly decreased serum biomarkers of hepatotoxicity (ALT, AST and ALP) renal toxicity (urea, creatinine), lipid peroxidation level, histological damage in liver and kidney. The protein and mRNA expressions of the transcription factor, Nrf2, and its target antioxidant genes (SOD1, CAT and GST) as well as activities of these antioxidant enzymes were downregulated by paracetamol administration but significantly recovered following the DQA treatment (Tab. 3, Fig. 5, Ref. 31). Text in PDF www.elis.sk KEY WORDS: acetaminophen/paracetamol, Drynaria quercifolia, renal toxicity, hepatotoxicity, Nrf-2.
\end{abstract}

\section{Introduction}

Paracetamol or acetaminophen is the most widely used antipyretic and analgesic drug across the globe (1) and has been included in the $20^{\text {th }}$ edition of World Health Organization List of essential medicines which was updated in 2017 (2). Paracetamol is frequently prescribed by clinicians and is also available over the counter (OTC). Given its vast usage and easy accessibility, the toxicity resulting from intentional or unintentional overdose of the drug is a matter of great concern. Paracetamol is metabolized in the liver, thus its acute or chronic overdose has a hepatotoxic impact. In the United States and United Kingdom, paracetamol overdose is the commonest cause of acute liver injury (3).

At therapeutic doses, paracetamol is metabolized largely through conjugation reactions resulting in the formation of phenolic sulphates or glucuronide conjugates which can be excreted. However, at higher doses, the conjugation reactions become saturated,

${ }^{1}$ Department of Zoology, West Bengal State University, Berunanpukuria, Malikapur, Barasat, Kolkata, West Bengal, India, and ${ }^{2}$ Ethnobotany and Medicinal Plant Research Laboratory, Department of Life Science \& Bioinformatics, Assam University, Silchar, Assam, India

Address for correspondence: S. Bhattacharjee, Department of Zoology, West Bengal State University, Berunanpukuria, Malikapur, North-24 Parganas, Barasat, Kolkata-700126, West Bengal, India.

Phone: 91-9831479164

Acknowledgement: Funded by The Department of Biotechnology (DBT), Govt. of India, under "Twinning Programme for North-East" (Sanction No. BT/PR16141/NER/95/81/2015 dtd. 7/11/2016. and the excessive paracetamol is oxidized by cytochrome P450 (CYP 450) to form the toxic metabolite $\mathrm{N}$-acetyl-p-benzoquinone imine (NAPQI) which can bind to sulfhydryl groups (-SH) of structural proteins creating oxidative stress $(1,4)$ Current treatment options for liver failure or liver diseases are limited and accompanied by several complications (5). Therefore, in view of the magnitude of paracetamol overdose problem, novel antidotes to counteract its toxicity are urgently needed. In this context, medicinal plants, especially those which are used by ethnic groups of a particular region for the treatment of various ailments, are of great interest.

Drynaria quercifolia (L.) J. Smith (Polypodiaceae) is an epiphytic medicinal pteridophyte native to tropical areas of Africa, Asia, Australia, Oceania, Western Australia as well as India, Southeast Asia, Malaysia, Indonesia, the Philippines and New Guinea (6). The indigenous tribes of various regions grind the rhizome of the fern into a paste and use it to treat various conditions. In Bangladesh, rhizomes are used in the treatment of excited mental disorders. In Southeast Asia, rhizome decoction of Drynaria is used as an antipyretic preparation. In Malaysia, fronds are used as poultice on swelling. In Tripura, India, the leaves and rhizome are used for the treatment of intestinal worms and abdominal pain. The rhizome is reported to be used by tribal communities of Tamil Nadu and Kerala to cure various diseases like phthisis, dyspepsia, and cough (7). The plant is used by the Nicobarese to treat body ache, headache and with other drugs in rheumatic pain (8). In Vietnam, the rhizome is used for the treatment of tuberculosis, rheumatism, osteodynia and dentalgia. Tribals in Kalakad Mundanthurai Tiger Reserve, India, use the rhizome of this fern to cure rheumatism. 
It is also reported that tonic prepared from Drynaria is beneficial to the liver and kidney and act astringent to the bowels during typhoid fever (9). Very recently, a study has reported a hepatoprotective effect of this fern against CCl4-induced rat liver fibrosis (10).

In this study, we wanted to test the hypothesis that an acetone extract prepared from the rhizome of Dryneria quercifolia (DQA) will be effective against paracetamol-induced toxicity in Swiss albino mice. The effect of the extract was tested on the site of paracetamol metabolism, which is the liver, the site of excretion, i.e., the kidney and the immune compartments, namely spleen and bone marrow of mice treated with an overdose of paracetamol. We have also determined the effect of the extract on the expression and activity of endogenous antioxidant enzymes such as superoxide dismutase (SOD), catalase (CAT) and glutathione-S-transferase (GST) and have studied its effect on the master regulator of the antioxidant system, redox-sensitive transcription factor, nuclear factor erythroid 2 - related factor 2 (Nrf2).

\section{Materials and methods}

\section{Chemicals}

DMEM media, Foetal Bovine Serum (FBS), and penicillinstreptomycin antibiotics were purchased from Gibco (Massachusetts, USA); antibodies against Nrf-2, SOD1, catalase, GST, and GAPDH were procured from Cell Signalling Technologies (Danvers, Massachusetts, USA); PVDF membrane was procured from Pall Corporation (New York, USA). The cDNA synthesis kit was obtained from Biobharati LifeScience Pvt.Ltd (Kolkata, West Bengal, India) and PCR master mix was purchased from Roche (Basel, Switzerland). The remaining materials were procured from local firms (India) and were of standard grade.

\section{Preparation of the extracts of plant materials}

The collected rhizome of the epiphytic pteridophyte Drynaria quercifolia has been cleaned thoroughly to avoid any unwanted materials. The cleaned rhizomes were then cut into small pieces, shade-dried and ground to powder with a mixer grinder. The powdered plant material was stored in airtight condition at room temperature while avoiding direct sunlight. The preparation of crude extract was done with Soxhlete apparatus (Borosil, Mumbai) using four solvents, viz., petroleum ether, ethyl acetate, acetone and methanol (Himedia, Mumbai). The powdered plant material was packed into a thimble using adsorbent paper and extracted subsequently with the above-mentioned solvents according to their ascending polarity. The four crude extracts were then processed through Rota-Vap to separate out the extra solvents and thereby to get solvent dried crude extracts. The dried crude extracts were further processed through SPE (Solid Phase Extraction) columns (StrataTM, Phenomenex, USA) using $40 \%, 60 \%, 80 \%$ and $100 \%$ methanol to get a more purified fraction.

\section{HPLC fingerprinting}

Analysis of all the standards and DQA was performed using Shimadzu Prominence series. In our experiment, the analytical column was reverse phase water guard column: Symmetry C18 (Luna $5 \mathrm{~mm}$ pore size) and the injection volumes of standards and samples were $10 \mathrm{ml}$. The peak area was calculated using Empower 2 software. Gradient elution of two solvents, viz., water (solvent A) and methanol (solvent B), was used in the mobile phase. The gradient program started with $20 \%$ solvent B and then linearly increased to $100 \%$ solvent $\mathrm{B}$ at a flow rate of $1 \mathrm{ml} / \mathrm{min}$. The samples were detected at $254 \mathrm{~nm}$. Identification was based on retention times and UV spectra by comparison with commercial standards.

\section{Estimation of total phenolic content}

We estimated the total phenolic content according to the FolinCiocalteu method. Undiluted Folin-Ciocalteu reagent in volume of $250 \mu \mathrm{l}$ was added to $50 \mu \mathrm{l}$ sample. After 1 minute we added $750 \mu 1$ of $20 \% \mathrm{w} / \mathrm{v}$ aqueous $\mathrm{Na}_{2} \mathrm{CO}_{3}$ and increased the volume to $5 \mathrm{ml}$ with $\mathrm{H}_{2} \mathrm{O}$. All the reaction reagents were present on the controls except for the extract. Then we measured the absorbance at $760 \mathrm{~nm}$ and compared it to the gallic acid calibration curve after $2 \mathrm{~h}$ of incubation at $25^{\circ} \mathrm{C}$. The estimation of the total phenol was measured as gallic acid equivalents ( $\mu$ g gallic acid/ mg extract) with values presented as means of triplicate analyses.

\section{Determination of total flavonoids}

Total flavonoid was determined by applying a slightly modified method of Meda et al. A sample of $0.25 \mathrm{ml}(1 \mathrm{mg} / \mathrm{ml})$ was added to a tube containing $1 \mathrm{ml}$ of double-distilled water. Then $0.075 \mathrm{ml}$ of $5 \% \mathrm{NaNO}_{2}, 0.075 \mathrm{ml}$ of $10 \% \mathrm{AlCl}_{3}$, and $0.5 \mathrm{ml}$ of $1 \mathrm{M} \mathrm{NaOH}$ were added sequentially at 0,5 , and $6 \mathrm{~min}$. Then, the volume of the reacting solution was adjusted to $2.5 \mathrm{ml}$ by adding doubledistilled water. The absorbance of the solution was measured at a wavelength of $410 \mathrm{~nm}$ using a spectrophotometer. Quercetin was used as a standard to determine the total flavonoid content of the extract of spice extracts. The results are presented in microgram quercetin equivalents $(\mathrm{QE})$ per $\mathrm{mg}(\mathrm{QE} / \mathrm{mg})$.

Determination of antioxidant activity by 1,1-diphenyl-2-picrylhydrazyl (DPPH) radical scavenging ability

1,1-Diphenyl-2-picrylhydrazyl (DPPH) radical-scavenging activity of extracts was measured by a slightly modified method of Brand-Williams (11). Briefly, $3 \mathrm{ml}$ of DPPH (Sigma, USA) solution $(0.1 \mathrm{mg} / \mathrm{ml})$ in $99.9 \%$ methanol was incubated with $0.1 \mathrm{ml}$ of different concentrations of the extract. The reaction mixture was shaken and incubated at room temperature in the dark for 25 min. The decrease in absorbance was then measured at $515 \mathrm{~nm}$.

\section{Haemolytic assay}

Fresh human blood was centrifuged at 4,000 Xg for $10 \mathrm{~min}$ and the cell pellet was washed thrice and re-suspended in $10 \mathrm{mM} \mathrm{PBS}$ at $\mathrm{pH} 7.4$ to obtain the final concentration of $1.6 \times 10^{9}$ erythrocytes $/ \mathrm{ml}$. Equal volumes of erythrocytes were incubated with varying concentrations of DQA while being shaken at $37{ }^{\circ} \mathrm{C}$ for $1 \mathrm{hr}$. The samples were then subjected to centrifugation at 3,500 $\mathrm{Xg}$ for 10 min at $4{ }^{\circ} \mathrm{C}$. RBC lysis was measured at different peptide concentrations by taking absorbance at an OD of $540 \mathrm{~nm}$. Complete 
110-119

haemolysis (100\%) was determined using $1 \%$ Triton X 100 as a control. Haemolytic activity of the active spice components was calculated in percentage using the following equation:

$\mathrm{H}=100 \mathrm{X}(\mathrm{Op}-\mathrm{Ob}) /(\mathrm{Om}-\mathrm{Ob})$

-where Op is the optical density of given peptide concentration, $\mathrm{Ob}$ is the optical density of buffer, and Om is the optical density of Triton X 100 .

\section{Cell culture}

$\mathrm{C} 2 \mathrm{C} 12$ cells were routinely maintained in RPMI 1640 supplemented with $10 \%$ foetal bovine serum, insulin $(0.1$ units $/ \mathrm{ml})$, L-glutamine $(2 \mathrm{mM})$, sodium pyruvate $(100 \mathrm{mg} / \mathrm{ml})$, nonessential amino acids $(100 \mathrm{mM})$, streptomycin $(100 \mathrm{mg} / \mathrm{ml})$, penicillin (50 unit $/ \mathrm{ml})$, and tetracycline (1 mg/ml) (Sigma Chemical Co.) at $37{ }^{\circ} \mathrm{C}$ in a humidified incubator containing $5 \% \mathrm{CO}_{2}$. The cells were then processed for the analysis of cell count and cell cycle.

\section{Animal model}

Male Swiss albino mice were maintained in plastic cages (6 mice per cage) at an ambient temperature of $22-25^{\circ} \mathrm{C}$ on a $12-\mathrm{h}$ light/dark cycle with ad libitum access to drinking water and pellet diet (NIN, Hyderabad, India). The use of animals was under strict animal care ethics guidelines of the university.

\section{Experimental groups}

All the animals were randomly divided into four groups of six animals per group: 1) vehicle-treated normal mice; 2) paracetamol $500 \mathrm{mg} / \mathrm{kg}$-treated control mice; and 3) paracetamol $500 \mathrm{mg} / \mathrm{kg}$ and DQA $1 \mathrm{mg} / \mathrm{kg}$-treated mice (Para+DQA 1); 4) paracetamol $500 \mathrm{mg} / \mathrm{kg}$-and DQA $4 \mathrm{mg} / \mathrm{kg}$-treated normal mice (Para+DQA 4). DQA was administered orally by gavage. These treatments were administered on alternated days through oral gavage route. At the end of 21 days, all the animals were sacrificed, and their liver, spleen, and bone marrow were harvested and used for the further analysis.

\section{Sera isolation}

Mice were anesthetized with the help of diethyl ether, and the blood was removed from the tail vein into collecting tubes. Serum was collected from freshly collected blood by allowing it to clot in a slanting position for $45 \mathrm{~min}$ and then it was centrifuged at $1,500 \mathrm{~g}$ for $30 \mathrm{~min}$ at $4{ }^{\circ} \mathrm{C}$. Finally, the serum samples were stored in different aliquots at $20^{\circ} \mathrm{C}$ for later use. All serum samples were thawed once, i.e., at the time of assay.

\section{Measurement of serum biochemical parameters}

Alanine aminotransferase (ALT), aspartate aminotransferase (AST), alkaline phosphatase (AP), urea and creatinine were measured from the collected sera using kits (Sigma).

\section{Preparation of bone marrow cells and splenocytes}

Femurs were aseptically removed from the untreated and experimental groups of mice. The bone marrow was then flushed with 26-gauge needles. Single-cell suspensions were made with repeated aspirations. The cells were resuspended in RPMI-1640.
The viable cell count was made in a haemocytometer by the trypan blue exclusion method.

\section{Dissection and tissue collection}

The liver tissues of the animals from all the experimental groups were collected; they were washed in $0.9 \%$ saline, soaked in filter paper, and processed for cellular, biochemical, and histological studies.

\section{Preparation of liver tissue}

A mass of $400 \mathrm{mg}$ of liver tissue was homogenized in $1.15 \%$ $\mathrm{KCl}$. Then the homogenate was centrifuged at $10,000 \mathrm{~g}$ at $4{ }^{\circ} \mathrm{C}$ for $20 \mathrm{~min}$. The supernatant was collected and used for quantitative estimation of lipid peroxidation (LPO), superoxide dismutase (SOD), catalase (CAT), and glutathione-S-transferase (GST)

\section{Assay of LPO by TBARS method}

For the assessment of hepatic lipid peroxidation level, the amount of thiobarbituric acid reactive substances (TBARS) was measured by a reaction with thiobarbituric acid (a product of lipid peroxidation) at $532 \mathrm{~nm}$ using spectrophotometer (12).

\section{CAT activity}

CAT activity was assessed by measuring the breakdown of $\mathrm{H}_{2} \mathrm{O}_{2}$ (13). The assay mixture consists of $3 \mathrm{ml}$ of $\mathrm{H}_{2} \mathrm{O}_{2}$ phosphate buffer and $0.05 \mathrm{ml}$ of the supernatant of the tissue homogenate. The change in absorbance was measured for $2 \mathrm{~min}$ at 30 -second intervals and $240 \mathrm{~nm}$ using a spectrophotometer.

\section{SOD activity}

SOD activity was measured based on pyrogallol auto-oxidation inhibition and expressed as unit/mg of protein (14). One unit of enzyme activity is defined as the amount of enzyme necessary for inhibiting the reaction by $50 \%$. Auto-oxidation of pyrogallol in Tris-HCL buffer $(50 \mathrm{mM}, \mathrm{pH} 7.5)$ is measured by the increase in the absorbance at $420 \mathrm{~nm}$.

\section{GST activity}

GST activities were measured in tissue cytosol by determining the increase in absorbance at $340 \mathrm{~nm}$ with 1- chloro-2,4-dinitrobenzene (CDNB) as substrate while the specific activity of the enzyme was expressed as a formation of CDNB-GSH conjugate/ $\mathrm{min} / \mathrm{mg}$ protein (15).

\section{Cell count in vitro and in vivo}

Cells from the culture of $\mathrm{C} 2 \mathrm{C} 12$ as well as those from bone marrow, and spleen were harvested. The viable cells were counted in a hemacytometer by the trypan blue exclusion method.

\section{Cell cycle distribution analysis}

For the determination of cell cycle phase distribution of nuclear DNA, the in vitro $\mathrm{C} 2 \mathrm{C} 12$ cells or those from bone marrow or spleen $\left(1 \times 10^{6}\right.$ cells $)$ were harvested. After making a single cell suspension, the cells were fixed with $3 \%$ p-formaldehyde and permeabilized with $0.5 \%$ Triton X-100. Then the nuclear DNA was labelled 

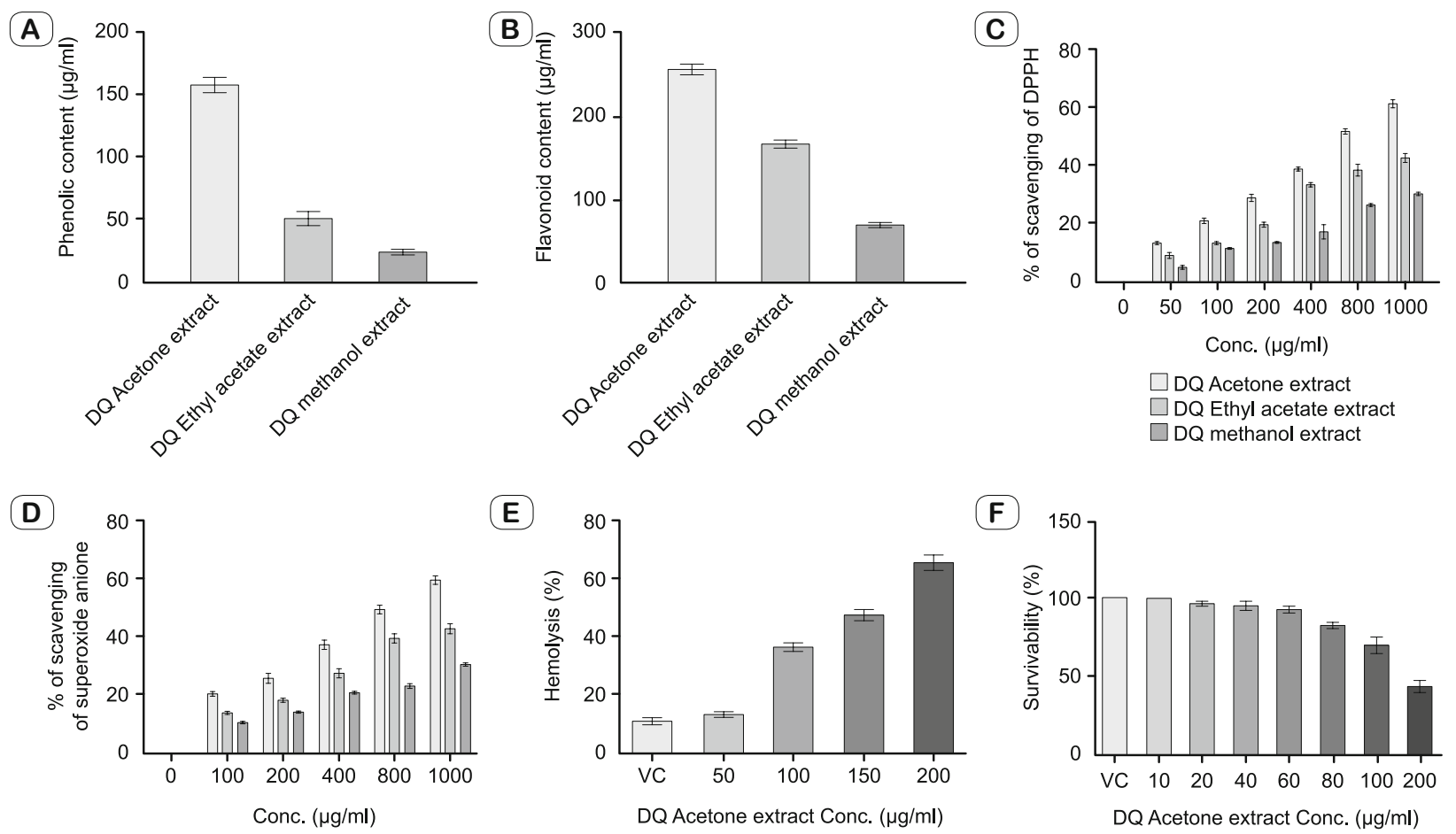

$\square$ DQ Acetone extract
$\square$ DQ Ethyl acetate extract
$\square$ DQ methanol extract

(G)

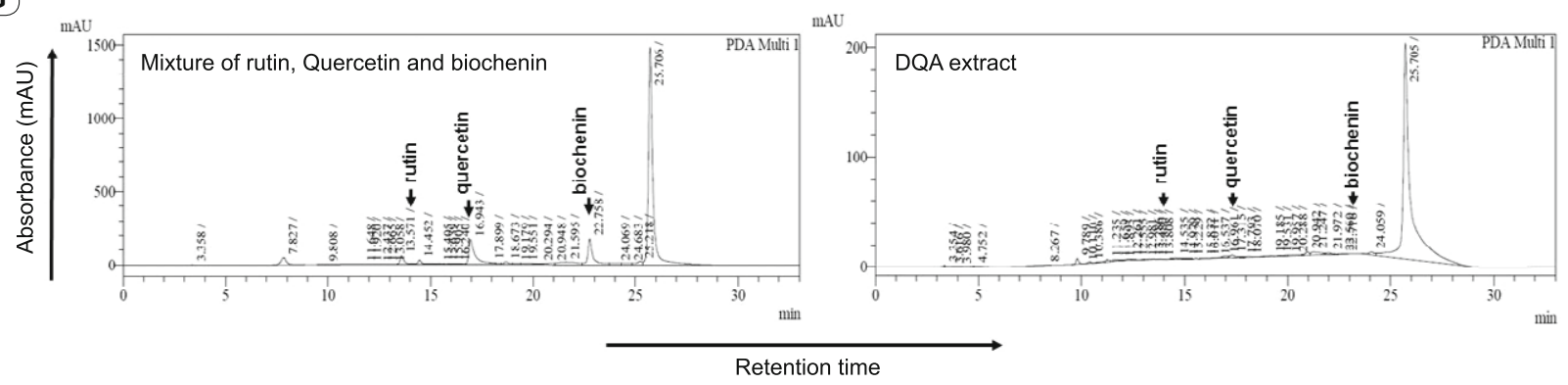

Fig. 1. Screening different fractions of Drynaria quercifolia extract based on their anti-oxidant properties and Characterization of most potent acetone fractions of Drynaria quercifolia extract (DQA). A. Total phenolic content $(\mu \mathrm{g} / \mathrm{mg})$ of acetone (DQA), ethyl acetate (DQEA) and methanol (DQMeOH) fractions of Drynaria quercifolia extract. B.Total flavonoid content $(\mu \mathrm{g} / \mathrm{mg})$ of DQA, DQEA and DQMeOH extracts. C. DPPH scavenging activity of DQA, DQEA and DQMeOH extracts at different concentrations (zero, 50, 100, 200, 400, $800 \mathrm{and} 1000 \mu \mathrm{g} / \mathrm{ml}) . \mathrm{C}$. Concentration dependent superoxide anion scavenging activity of DQA, DQEA and DQMeOH extracts. D. Percentage of haemolysis by DQA at different concentrations $(50,100,150$ and $200 \mu \mathrm{g} / \mathrm{ml})$. F. Cell viability percentage of murine C2C12 at different concentrations of DQA (10, $20,40,60,80,100$ and $200 \mu \mathrm{g} / \mathrm{ml})$. G. HPLC chromatogram of acetone fraction of Drynaria quercifolia extract (DQA). The peaks indicate the presence of following components rutin; biochenin; and quercetin.

with propidium iodide (PI, $125 \mathrm{mg} / \mathrm{ml}$ ) after RNase treatment. The cell cycle phase distribution of nuclear DNA was determined on FACS Calibur, and the CellQuest software was used (Becton Dickinson). Histogram display of DNA content (x-axis, PI fluorescence) versus counts (y-axis) has been displayed. Statistics was employed to quantitate the data at different phases of the cell cycle.

\section{Cell quest detection of gene expression by qRT-PCR}

Total RNA from the liver tissue was isolated using TRIzol (Applied Biosystems/Ambion, Austin, TX, USA). The concen- tration and purity of the isolated RNA was determined by spectrophotometer at $260 \mathrm{~nm}$ and $280 \mathrm{~nm}$. Reverse transcription was performed using MMLV Reverse Transcriptase (NEB, UK). A mix of $2 \mu \mathrm{g}$ total RNA and $2 \mu \mathrm{L}$ of random primers (NEB, UK) was incubated in a total volume of $15 \mu \mathrm{l}$ for $5 \mathrm{~min}$ at $70{ }^{\circ} \mathrm{C}$ and kept for cooling on ice. After adding $5 \mu \mathrm{L}$ of MMLV $5 \times$ Reaction Buffer (NEB, UK), 10mM dNTPs, $1 \mu \mathrm{L}$ ribonuclease inhibitor (NEB, UK) and $2 \mu \mathrm{L}$ of MMLV reverse transcriptase to reach the total volume of $25 \mu \mathrm{L}$. The reaction mix was incubated again for $1 \mathrm{~h}$ at $45^{\circ} \mathrm{C}$. PCR reactions were performed using Hot Start Taq 
110-119

(A)

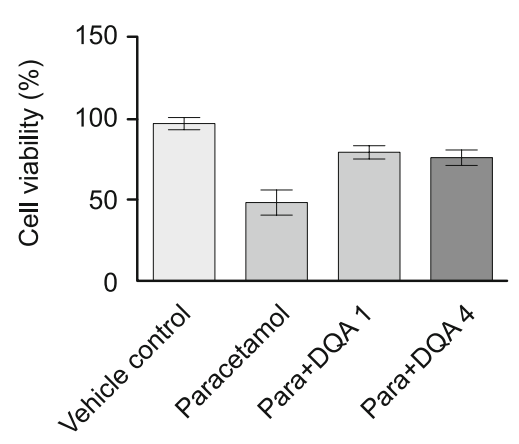

B

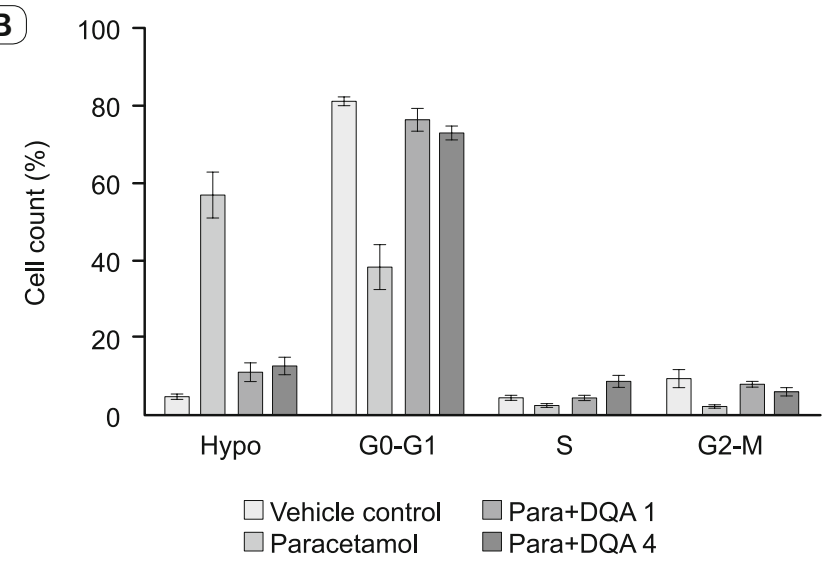

(C)

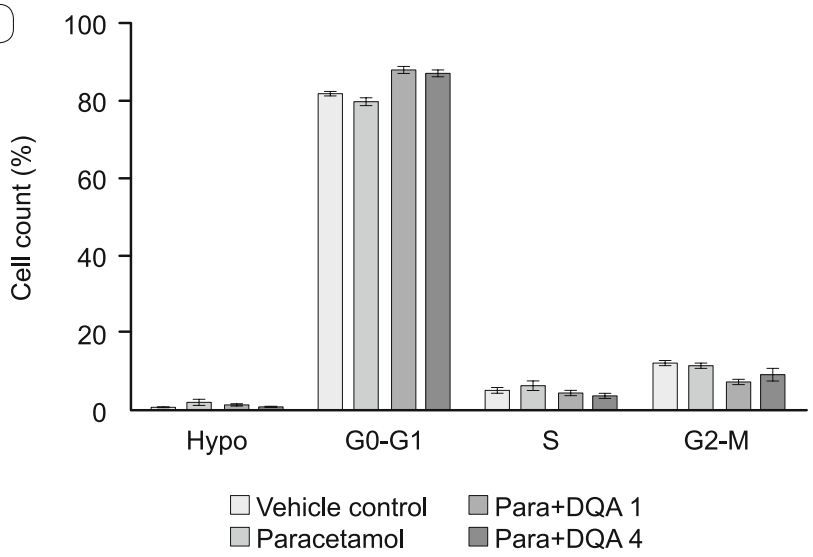

Fig. 2. Recovery of in vivo Paracetamol-induced toxicity by acetone fractions of Drynaria quercifolia extract (DQA) among splenic cells. A. Percentage of cell viability of spleen cells in paracetamol-induced swiss albino mice compared to additional DQA-treated mice as assessed by trypan blue exclusion assay. B. Flowcytometric detection of the effect of DQA on cell cycle phase distribution of Paracetamol-induced swiss albino mice. Bar diagram represents cell cycle phase distribution of spleen cells from different experimental groups. C. Percentage of cell viability of bone marrow cells in paracetamol-induced swiss albino mice compared to additional DQA-treated mice as assessed by trypan blue exclusion assay. D. Flowcytometric detection of the effect of DQA on cell cycle phase distribution of Paracetamol-induced swiss albino mice. Bar diagram represents cell cycle phase distribution of bone marrow cells from different experimental groups. The data represented as mean \pm S.D. for the three different experiments performed in triplicate.

2X Master Mix (NEB, UK) in reaction mixes containing $10 \mathrm{nM}$ of each primer, 1-4 $\mu \mathrm{L}$ cDNA, and PCR buffers as supplied by the manufacturer, in a total volume of $25 \mu \mathrm{L}$. PCR primers were designed based on sequences deposited in the Primer 3 database. Real-time PCR was performed using Power SYBR Green Master Mix. Quantitative RT-PCR was run using a sds7500 FAST sequence detection system. Data were analyzed with Singleplex (Applied Biosystems, CA). Each PCR was performed in triplicate at least 3 times independently. The gene expressions were normalized to GAPDH and relative changes were determined using the $\Delta \Delta \mathrm{Ct}$ method.

\section{Western blot analysis}

Liver cell lysates from in vivo models were obtained and equal amounts of protein from each sample were diluted with loading buffer, denatured, and separated by $10 \%$ sodium dodecyl sulphate-polyacrylamide gel electrophoresis (SDS-PAGE) followed by protein transfer to polyvinylidene fluoride membranes (PVDFs). The effect of DQA treatment on the expression of Nrf2, SOD, CAT, GST, and GAPDH was determined. Protein was detected by incubation with the corresponding primary antibodies (anti-Nrf2, anti-SOD, anti-Catalase, anti-GST) and followed by blotting with HRP-conjugated secondary antibody. The blots were then detected using a chemiluminescent kit ((ImmunoCruz Western Blotting Luminol reagent, sc-20489). This analysis was performed three times.

\section{Histopathological assessment}

Liver and kidney tissues were fixed overnight at $4{ }^{\circ} \mathrm{C}$ in freshly prepared $4 \%$ paraformaldehyde and then dehydrated in graded alcohols and embedded in paraffin. Sections of $5 \mathrm{~mm}$ in thickness were cut from representative paraffin blocks. Liver tis- 
A

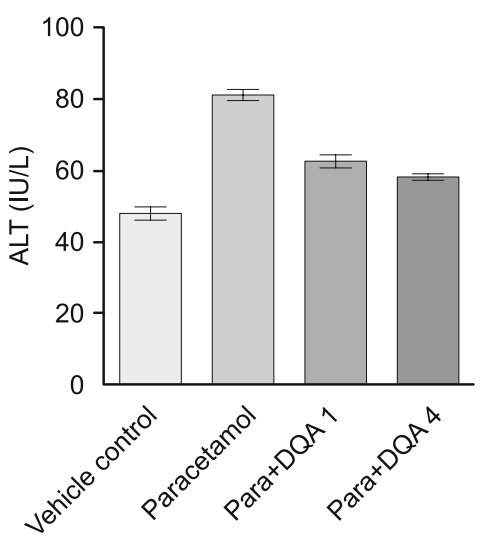

C

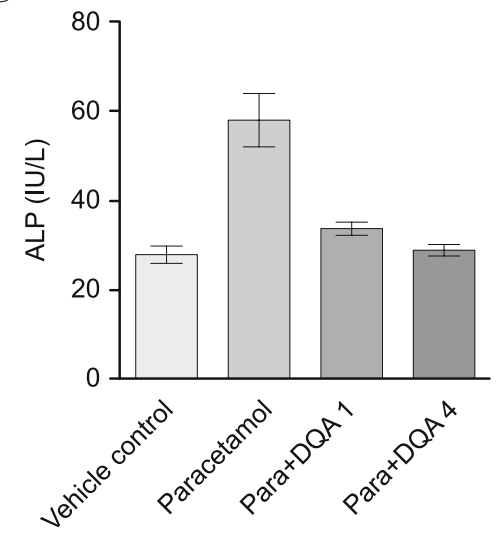

B

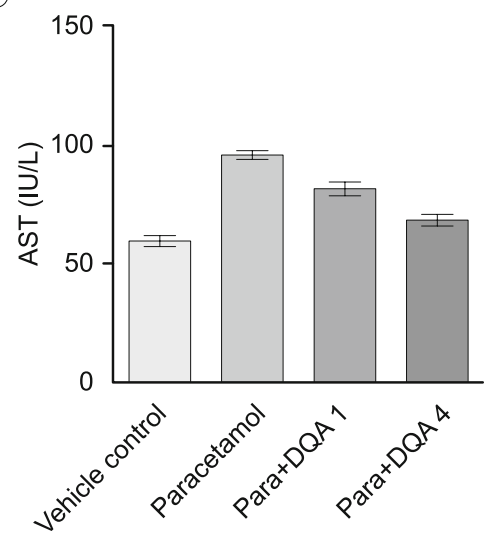

(D)

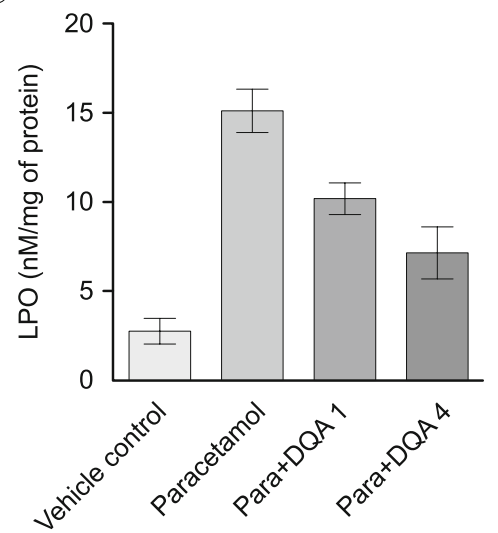

E
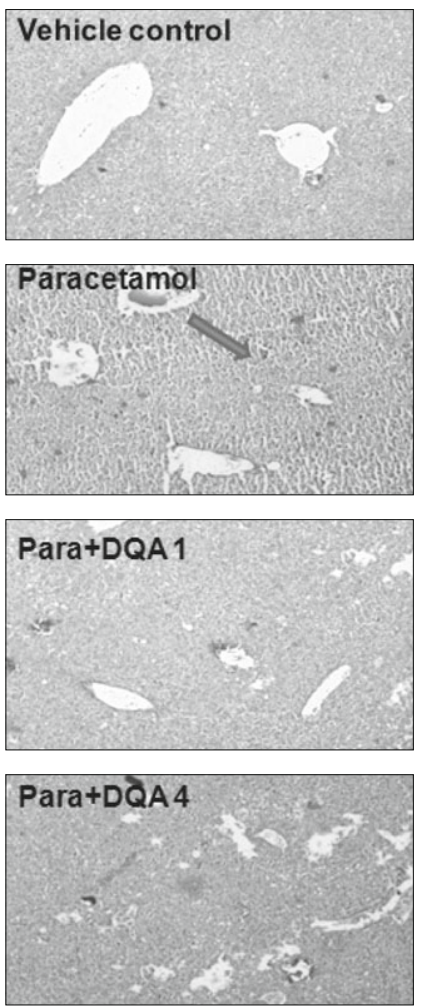

Fig. 3. Hepatoprotective effect of acetone fraction of Drynaria quercifolia (DQA) in Paracetamol-induced mice. A.-D. Status of different biomarkers for serum hepatotoxicity such as (A.) serum alanine aminotranferase (ALT); (B.) serum aspartate transaminase (AST); (C.) serum alkaline phosphatase (ALP) and lipid peroxidation (LPO) in liver tissue of different experimental groups (D.). E. Representative H-E stained liver tissue sections from different experimental groups. The data represented as mean \pm S.D. for the three different experiments performed in triplicate.

sues were cut right through the middle of the tissues to obtain the central core region. The sections were rehydrated and stained with haematoxylin and eosin. The degree of liver damage on microscopic cross sections was scored by a pathologist in a blinded fashion following a modified Brunt System (16). Four histologic features: steatosis, hepatocyte ballooning, portal inflammation, and lobular inflammation were considered to score the grade of liver damage.

\section{Statistical analysis}

One way ANOVA was used to analyse statistical differences. A pvalue of $<0.05$ was considered statistically significant difference.

\section{Results}

The antioxidant potential of Drynaria quercifolia extracts

The total phenolic and flavonoid content of acetone, ethyl acetate and methanol extracts of Drynaria was determined using gallic acid and quercetin, respectively, as standards and expressed as gallic acid equivalent (GAE) $\mathrm{mg}^{-1}$ and quercetin equivalent (QE) $\mathrm{mg}^{-1}$. DQA showed the highest phenol and flavonoid content with values of $148.42 \pm 3.820 \mathrm{GAE} \mathrm{mg}^{-1}$ extract, and $248 \pm 4.329$ QE mg-1 extract, respectively (Fig. 1A, B). Several studies have confirmed that plant extracts rich in phenol and flavonoids exert potent antioxidant activities. Accordingly, we then measured the ability of the extracts to scavenge DPPH and superoxide radicals. All the extracts were found to exhibit a dose-dependent increase in DPPH and superoxide radical scavenging activities (Fig. 1C, D). At various tested concentrations (50-1000 mg), DQA was found to be the post-potent radical scavenger. Therefore, we performed all our subsequent experiments with DQA.

\section{Dose verification in terms of toxicity}

The cytotoxicity of various concentrations of DOA was tested in human erythrocytes by hemolytic assay and in normal mouse $\mathrm{C} 2 \mathrm{C} 12$ cell line. The haemolytic assay showed that up to $200 \mu \mathrm{g} /$ $\mathrm{mL}$ concentration, the haemolysis is less than $5 \%$. So, the concentration up to $200 \mu \mathrm{g} / \mathrm{mL}$ can be used for further experiments. 
110-119

Tab. 1. Measurement of serum biomarkers of hepatotoxicity.

\begin{tabular}{lccc}
\hline Serum parameters & $\begin{array}{c}\text { Normal } \\
\text { control group }\end{array}$ & $\begin{array}{c}\text { Paracetamol }(500 \mathrm{mg} / \mathrm{kg}) \\
\text { control group }\end{array}$ & $\begin{array}{c}\text { Paracetamol }(500 \mathrm{mg} / \mathrm{kg}) \\
+ \text { DQA } 1 \mathrm{mg} / \mathrm{kg} \text { body weight }\end{array}$ \\
\hline ALT(IU/L) & $48.2 \pm 2.23$ & $78.4 \pm 4.42$ & $62.02 \pm 3.29$ \\
AST(IU/L) & $56.6 \pm 2.56$ & $92.9 \pm 1.92$ & $80.34 \pm 3.24$ \\
ALP(IU/L) & $30.2 \pm 1.34$ & $48.3 \pm 4.56$ & $31.23 \pm 4.63$ \\
\hline
\end{tabular}

In a normal mice cell line $\mathrm{C} 2 \mathrm{C} 12$, the $\mathrm{subG}_{0}$ cell population is less than $10 \%$ after administration of DQA up to $100 \mu \mathrm{g} / \mathrm{ml}$ concentration. The cell count data of $\mathrm{C} 2 \mathrm{C} 12$ cell line also showed that the highest concentration of DQA, that is $100 \mu \mathrm{g} / \mathrm{mL}$, showed $9.25+1.35 \%$ of killing. So, we selected two optimum concentrations of DQA $(20 \mu \mathrm{g} / \mathrm{mL}$ and $80 \mu \mathrm{g} / \mathrm{mL})$ for further analysis (Fig. 1 E, F).

\section{Fingerprint analysis of DQA by HPLC}

To establish the fingerprint chromatogram for the quality control of DQA, gallic acid, rutin, quercetin, biochanin A, quercetin, eugenol, anethol and eucaliptol etc., were used as standards. HPLC chromatograms showed three marker components present in the extract. As shown in Figure $1 \mathrm{G}$, the phytochemicals that could be identified in DQA based on their retention time and UV absorbance of purified standards, are as follows: rutin, quercetin, and biochanin $\mathrm{A}$.
DQA ameliorates paracetamol-induced hypocellularity in spleen

Based on the above-mentioned in vitro concentrations, two in vivo doses, viz. $1 \mathrm{mg} / \mathrm{kg}$ and $4 \mathrm{mg} / \mathrm{kg}$ body weight were determined by extrapolating the in vitro doses taking into consideration the weight and total blood volume of mice. Significant cell death was observed in the spleen in the paracetamol control group as indicated by an increased number of non-viable cells $(58.15 \pm 3.23 \%)$ and increased subG $_{0}$ cell population $(51.12 \pm 2.76 \%)$ as compared to normal vehicle control group. DQA treatment could ameliorate this cytotoxicity induced by paracetamol in spleen. DQA treatment caused a dose-dependent reduction in splenic cell death with 37.11 $\pm 2.23 \%$ and $20.12 \pm 2.67 \%$, respectively for DQA $1 \mathrm{mg} / \mathrm{kg}$ b.w. and DQA $4 \mathrm{mg} / \mathrm{kg}$ b.w. (Fig. 2A). Similarly, the subG population $^{2}$ was also reduced in the two DQA-treated groups $(2.34 \pm 0.98$ and $3.78 \pm 67 \%$ for the low dose and high dose, respectively) (Fig. 2B). The bone marrow cellularity, however, remained unaffected by paracetamol or DQA treatments (Fig. 2C, D).

A

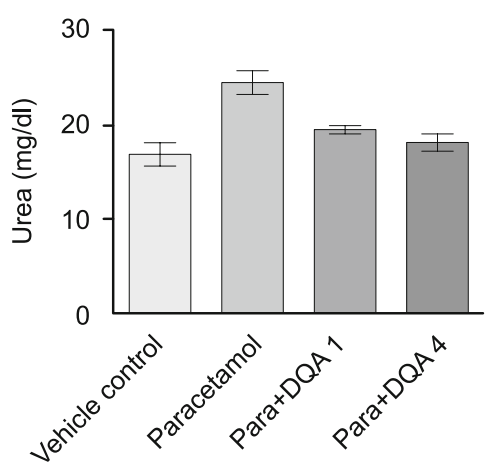

C
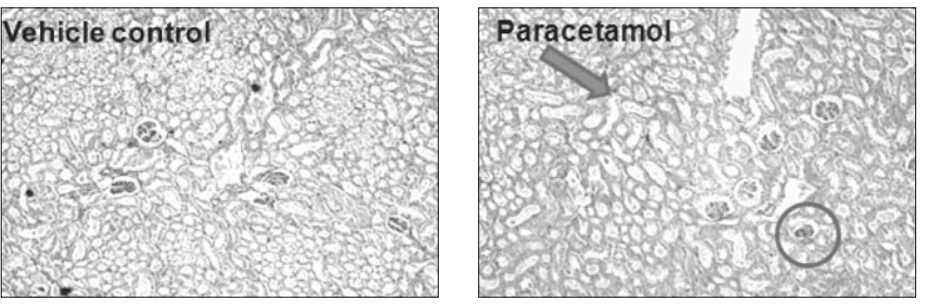

B
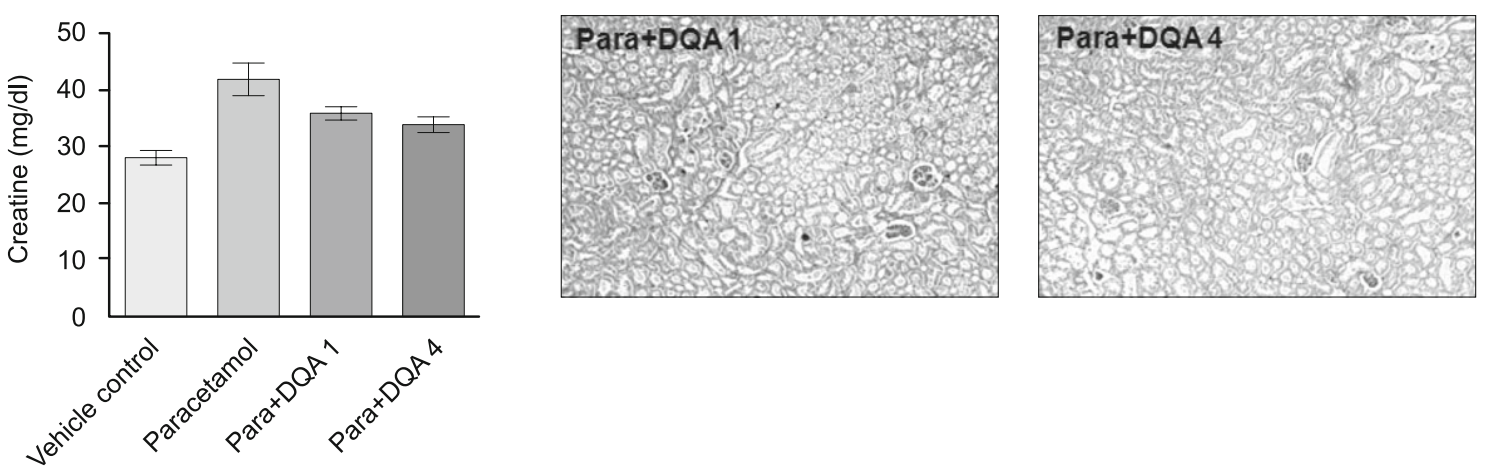

Fig. 4. Recovery of renal toxicity by acetone fraction of Drynaria quercifolia (DQA) in Paracetamol-induced mice. A.-B. Level of different serum biomarkers for renal toxicity, such as (A.) urea and (B.) creatinine of different experimental groups. C. Representative H-E stained kidney tissue sections from different experimental groups. The data represented as mean \pm S.D. for the three different experiments performed in triplicate. 
Tab. 2. Measurement of serum biomarkers of renal toxicity.

\begin{tabular}{lccc}
\hline Serum parameters & $\begin{array}{c}\text { Normal } \\
\text { control group }\end{array}$ & $\begin{array}{c}\text { Paracetamol }(500 \mathrm{mg} / \mathrm{kg}) \\
\text { control group }\end{array}$ & $\begin{array}{c}\text { Paracetamol }(500 \mathrm{mg} / \mathrm{kg}) \\
+\mathrm{DQA} 1 \mathrm{mg} / \mathrm{kg} \text { body weight }\end{array}$ \\
\hline Urea & $19.2 \pm 1.23$ & $22.3 \pm 2.34$ & $20.45 \pm 0.78$ \\
Creatinine & $0.15 \pm .03$ & $0.19 \pm .08$ & $0.18 \pm 0.09$ \\
\hline
\end{tabular}

A

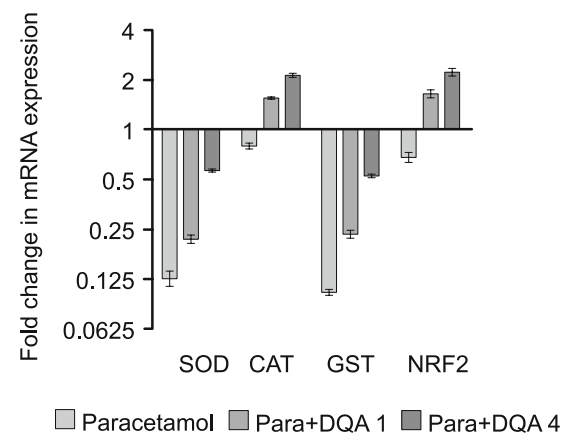

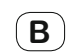

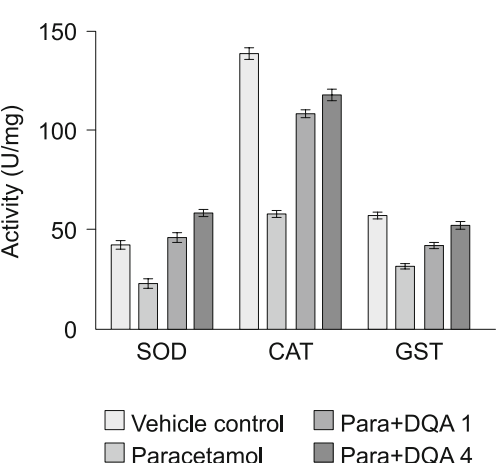

(C)

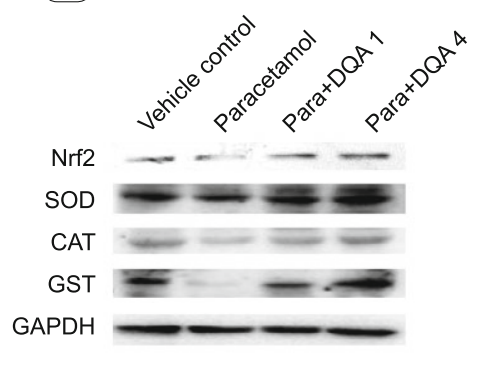

Fig. 5. Acetone fraction of Drynaria quercifolia (DQA) promoted Nrf-2 mediated antioxidant gene regulation in paracetamol-induced mice. A. Relative mRNA expression of SOD1, CAT, GST and Nrf-2 in different experimental groups as assessed by qPCR. B. Enzymatic activity of Sod1, Cat and GST in liver tissue of different experimental groups. C. Expression of Nrf-2, SOD1, CAT, GST .Equal loading of protein in the lanes is confirmed by GAPDH. The data represented as mean \pm S.D. for the three different experiments performed in triplicate.

Hepatotoxicity induced by paracetamol in mice is reduced by $D Q A$

The hepatotoxicity induced by paracetamol was confirmed by measuring the serum ALT, AST, and ALP levels. In the paracetamol control group, all the serum markers for liver function were significantly higher as compared to the normal control group. As shown in Figures $3 \mathrm{~A}-\mathrm{C}$, the DQA treatment could dose-dependently reduce paracetamol-induced hepatotoxicity as indicated by the lowered values of these serum biomarkers of hepatotoxicity (Tab. 1).

Hepatic oxidative stress was quantified by measuring the lipid peroxidation level in the liver. There was a robust increase in the level of hepatic lipid peroxidation in the paracetamol control group (17.34 $\pm 1.2 \mathrm{nM}$ TBARS/mg protein) as compared to that seen in the normal liver $(1.34 \pm .045 \mathrm{nM}$ TBARS/mg protein). Treatment with both doses of DQA could significantly reduce paracetamolinduced hepatic oxidative stress as indicated by reduced levels of hepatic lipid peroxidation in the two DQA-treated groups (5.3 $\pm 3.43 \mathrm{nM}$ TBARS/mg protein and $8.45 \pm 2.34 \mathrm{nM}$ TBARS/mg protein) (Fig. 3D).

Hepatotoxicity was also assessed by haematoxylin and eosin staining of liver sections of mice intoxicated with paracetamol for 21 days. The paracetamol-treated liver showed severe hepatocellular necrosis, fibrotic changes and pseudolobulation. Mice liver sections treated with DQA showed lesser fibrotic changes when compared to paracetamol-treated group (Fig. 3E).

Renal toxicity induced by paracetamol in mice is reduced by DQA

Renal toxicity measured by serum urea and creatinine level also reflected the same results as hepatotoxicity. Paracetamol treatment caused a significant increase in serum urea and creatinine levels as compared to normal mice. DQA could lower the paracetamol-induced increase in serum biomarkers of kidney function. The results are plotted in Figures 4 A, B and tabulated in Table 2. Renal toxicity was also ascertained by performing histopathology of haematoxylin and eosin-stained kidney sections of mice belonging to different experimental groups. The paracetamol-treated kidneys showed glomerular inflammation, mesangial thickening and lobulation which were significantly recovered in kidney sections of DQA-treated mice (Fig. 4 C).

Protective effect of acetone fraction of Drynaria quercifolia by modulation of Nrf2 and its targeted genes

After 21 days of paracetamol administration on alternative days, the paracetamol control mice showed a reduced level of Nrf2 transcripts (Fig. 5A). This decreased expression was coupled with downregulation of Nrf2 regulated genes, viz., SOD, CAT, and GST mRNA (Fig. 5A). Enzyme activity studies revealed reduced activities of these antioxidant enzymes in the paracetamol control group (Fig. 5B). Interestingly, in the group where paracetamol was interspaced with DQA treatment for 21 days on alternative days, the Nrf2 levels were significantly enhanced (Fig. 5A). Expressions of genes transactivated by Nrf2, such as SOD, CAT and GST followed the queue with increased levels of their transcripts (Fig. 5A). The increased mRNA levels were also translated into increased enzymatic activities of all the above-mentioned enzymes (Fig. 5B). The activities of antioxidant enzymes are listed in Table 3. Western blot analysis showed the same trend as mRNA expression studies. There was a significant inhibition in Nrf2 pro- 
Tab. 3. Antioxidant enzymes activity.

\begin{tabular}{|c|c|c|c|c|}
\hline $\begin{array}{l}\text { Antioxidant enzymes } \\
\text { activity }\end{array}$ & $\begin{array}{c}\text { Normal } \\
\text { control group }\end{array}$ & $\begin{array}{c}\text { Paracetamol }(500 \mathrm{mg} / \mathrm{kg}) \\
\text { control group }\end{array}$ & $\begin{aligned} & \text { Paracetamol }(500 \mathrm{mg} / \mathrm{kg}) \\
+ & \text { DQA } 1 \mathrm{mg} / \mathrm{kg} \text { body weight }\end{aligned}$ & $\begin{array}{l}\text { Paracetamol ( } 500 \mathrm{mg} / \mathrm{kg}) \\
+4 \mathrm{mg} / \mathrm{kg} \text { body weight }\end{array}$ \\
\hline SOD (unit/mg of protein) & $38 \pm 1.2$ & $19 \pm 0.98$ & $42 \pm 1.11$ & $58 \pm 2.2$ \\
\hline CAT (unit/mg of protein) & $139 \pm 1.67$ & $59 \pm 0.34$ & $112 \pm 2.34$ & $118 \pm 2.18$ \\
\hline GST (unit/mg of protein) & $56 \pm 1.69$ & $22 \pm 1.55$ & $43 \pm 1.13$ & $56 \pm 1.99$ \\
\hline
\end{tabular}

tein level which was accompanied by reduced protein levels of SOD, CAT and GST in the paracetamol control group. However, the interspaced DQA administration successfully ameliorated this suppressed Nrf-2 and its target antioxidant gene expressions both at the mRNA and protein levels.

\section{Discussion}

Acetaminophen is probably the most popular and safe drug preferred by victims of pain or pyrexia (17). Its prevalence in use is irrespective of gender, age or geographic considerations. Even the US FDA agrees that paracetamol/acetaminophen, either alone or in combination with other molecules, is available as over-the-counter medication (18). This easy availability of the potent drug often lures to its unintentional overdoses or overuse. This easy availability and its related abuse are the reason for its name being associated with hepatotoxicity and acute liver failure (19). Alarmingly, paracetamol accounts for $46 \%$ of all acute liver failures in the US, while in Great Britain, this percentage is $40 \%$ and in Europe it is a staggering $70 \%$ of all cases (20). The concern is further heightened by the fact that acetaminophen accounts for nearly 500 annual deaths in the U.S. alone, and as many as 100,000 calls to US Poison Control Centers with about 50,000 emergency room visits and 10,000 hospitalizations each year (20). The concern is also reflected by the fact that this particular issue found its prominence in two US-FDA Advisory Committee meetings in the past 15 years.

Although acetaminophen-induced liver toxicity is currently treated with $N$-acetyl-cysteine (NAC), which is documented for restoring cellular glutathione (GSH) stores in the liver, a huge number of plant extracts and phytochemicals are also being considered as a possible and effective alternative to counter this drug-induced toxicity (21). Plant products, both as extracts or their purified components, either alone or in combination with each other or other synthetic molecules have been considered for remedial options (21). This option achieves its rationale from enormous amount of data that account for their ability to act as a restorer of cellular antioxidant defence system, thereby countering the drug-induced hepatic oxidative stress, which in turn protects the organ from cellular mitochondrial perturbation leading to inflammatory processes (21).

In the present study, we explored the potentiality of acetone extract of Drynaria quercifolia (DQA), also referred to as oakleaf fern, in abrogation of paracetamol-induced hepatotoxicity in a murine model. We have used orally administered paracetamol 500mg/ $\mathrm{kg}$ body weight on alternate days for a period of 21 days to mimic the use of the said drug at a high dose on a chronic level. DQA was administered 24 hours after each $500 \mathrm{mg} / \mathrm{kg}$ of paracetamol dosage, keeping in mind that if administered together it might directly interfere with drug activity as well as cause adverse side effects $(22,23)$. Some plant products have been reported to affect the blood availability of various conventional medicines by altering the cytochrome $\mathrm{P} 450$ activity or P-glycoprotein-mediated cellular absorption or elimination system $(22,24)$. For example, both Allium sativum (25) and Hibiscus sabdariffa (26) have been reported to have an influence on the pharmacokinetic variables of paracetamol. Moreover, DQ has been reported to have anti-inflammatory and analgesic properties which in turn could act to complement the rationale of the use of paracetamol without interfering in its activity (27). Having set the rationale for the dose and treatment regime, we tested the ameliorative effect of acetone extract of Drynaria quercifolia against paracetamol-induced hepatic toxicity.

Our in vitro experimentations revealed DQA to contain a considerable amount of phenol and flavonoid content which contributed to its effective (greater than $50 \%$ ) DPPH scavenging activities. By means of toxicological evaluation using hemolytic assay and its cytotoxicity against $\mathrm{C} 2 \mathrm{C} 12$ cell line, we ascertained the two doses of DQA, viz. $1 \mathrm{mg} / \mathrm{kg}$ and $4 \mathrm{mg} / \mathrm{kg}$ body weight.

Studies and postulates reveal that acetaminophen inhibits COX2 and repeated exposure to such inhibition affects mucosal PGE2 synthesis as well as maturational immunity $(28,29)$. The acetaminophen-like drugs can lead to altered immune response such as hypersensitivity, which further links the drug to immune dysfunction (30). Our data further link the overdosage of paracetamol with immune cytotoxicity. Our observations revealed that there was a severe cytotoxicity in the spleen at the mentioned dose and treatment schedule of paracetamol. Interestingly, DQA treatment could avert such hypocellularity and reduce paracetamol-induced cytotoxicity in the mentioned immune sites.

In our study, we found paracetamol to induce severe hepatic tissue damage, which was evident from histological findings; however, DQA treatment successfully prevented the fibrotic changes induced by paracetamol. Furthermore, lipid peroxidation in liver tissues revealed that paracetamol induced a severe oxidative stress leading to organ damage which resulted in higher levels of serum ALT, AST, and ALP. The DQA treatment could significantly decrease the oxidative stress in the liver and lower the serum bio markers, thereby assuring hepatic relief.

Molecular investigation into the mechanistic evaluation of DQA action against paracetamol-induced hepatic toxicity revealed that paracetamol downregulated the antioxidant regulator Nrf2 gene expression which further abrogated its downstream targets, viz. SOD, CAT, and GST gene expressions. Enzyme activity studies also revealed that the said enzymes were less active in paracetamol treatment groups. DQA administration could restore the Nrf2 expression and reinstate the increased activity of SOD, CAT, and 
GST, thereby rendering protection against paracetamol-induced oxidative stress in the liver. Interestingly, the DQ ethyl acetate extract fraction was found to prevent CCl4-induced liver fibrosis by inhibition of NFKB-signaling pathway and activation of antioxidant response through increased expression of $\mathrm{Nrf2}$ (10).

An acetaminophen overdose is also known to cause renal complications (31). In our study, we also traced the increased serum renal toxicity markers (urea, creatinine) in paracetamol groups along with renal histological evaluation of the organ.

Renal toxicity was also confirmed by severe glomerular inflammation, mesangial thickening and lobulation. DQA treatment could significantly ameliorate such toxic manifestations in renal tissues.

To conclude, DQA treatment not only prevented paracetamol-induced hepatic distress following chronic exposure of the drug but also ameliorated its immune and renal toxicity.

\section{References}

1. Athersuch TJ, Antoine DJ, Boobis AR, Coen M, Daly AK, Possamai L, Nicholson JK, Wilson ID. Paracetamol metabolism, hepatotoxicity, biomarkers and therapeutic interventions: a perspective. Toxicol Res (Camb) 2018; 7 (3): 347-357.

2. https://www.who.int/medicines/publications/essentialmedicines/en/.

3. Bateman DN, Carroll R, Pettie J, Yamamoto T, Elamin ME, Peart L, Dow M, Coyle J, Cranfield KR, Hook C, Sandilands EA, Veiraiah A, Webb D, Gray A, Dargan, PI, Wood DM, Thomas SH, Dear JW, Eddleston M. Effect of the UK's revised paracetamol poisoning management guidelines on admissions, adverse reactions and costs of treatment. Br J Clin Pharmacol 2014; 78 (3): 610-618.

4. Vliegenthart AD, Antoine DJ, Dear JW. Target biomarker profile for the clinical management of paracetamol overdose. Br J Clin. Pharmacol 2015; 80 (3): 351-362.

5. Bishayee A, Darvesh AS, Politis T, McGory R. Resveratrol and liver disease: from bench to bedside and community. Liver Int 2010; 30: 1103-1114.

6. Prasanna G, Anuradha R. A Comprehensive Review on Phytopharmacological Activities of Drynaria quercifolia L. Int J Pharmacogn Phytochem Res 2016; 8 (8): 1304-1313.

7. Cairus JF. The medicinal and poisonous plants of India. 1986.

8. Dagar J, Dagar HS. Ethnobotanical and other uses of some Gymnosperms found in Andaman and Nicobar Islands. J Econom Taxonom Botany 1987; 9: 201-204.

9. Saxena PK, Gill R, Rashid A. Optimal conditions for plant regeneration from mesophyll protoplasts of eggplant (Solanum melongena L.). Scientia Horticulturae 1987; 31: 185-194.

10. Anuja G, Shine V, Latha P, Suja S. Protective effect of ethyl acetate fraction of Drynaria quercifolia against $\mathrm{CCl} 4$ induced rat liver fibrosis via Nrf2/ARE and NFKB signalling pathway. J Ethnopharmacol 2018; 216 : $79-88$.

11. Brand-Williams W, Cuvelier ME, Berset CLWT. Use of a Free Radical Method to Evaluate Antioxidant Activity. LWT-Food Sci Technol 1995; 28: $25-30$.

12. Ohkawa H, Oshisi N, Yagi K. Assay for lipid peroxides in animal tissues by thiobarbituric acid reaction. Anal Biochem 1979; 95 (2): 351-358.
13. Luck H. Catalase. In: Bergmeyer HU (Ed). Method of Enzymatic Analysis, Academic Press, New York and London, 1965; 885-894.

14. Marklund S, Marklund G. Involvement of the Superoxide anion radi$\mathrm{cal}$ in the autoxidation of pyrogallol and a convenient assay for superoxide dismutase. Eur J Biochem 1974; 47 (3): 469-474.

15. Habig WH, Pabst MJ, Jakoby WB. Glutathione Stransferase. J Biol Chem 1974; 249 (22): 7130-7139.

16. Merat S, Khadem-Sameni F, Nouraie M, Derakhshan M H, Tavangar SM, Mossaffa S, Malekzadeh R, Sotoudeh M, A modification of the Brunt system for scoring liver histology of patients with non-alcoholic fatty liver disease. Arch Iran Med 2010; 13 (1): 38-44.

17. Ramachandran A and Jaeschke H. Acetaminophen Hepatotoxicity. Semin Liver Dis 2019; 39 (2): 221-234.

18. Acetaminophen https://www.fda.gov/drugs/drugsafety/informationbydrugclass /ucm165107.htm.

19. Moore N, Scheiman J. Gastrointestinal safety and tolerability of oral non-aspirin over-the-counter analgesics. Postgrad Med 2018; 130 (2): $188-199$.

20. Lee $\mathbf{Q}$, Hypersensitivity to antipyretics: pathogenesis, diagnosis, and management. Hong Kong Med J 2017; 23 (4): 395-403.

21. Subramanya S, Venkataraman B, Meeran M, Goyal S, Patil C, Ojha S. Therapeutic Potential of Plants and Plant Derived Phytochemicals against Acetaminophen-Induced Liver Injury. Int J Mol Sci 2018; 19 (12): 3776.

22. Izzo A. Interactions between Herbs and Conventional Drugs: Overview of the Clinical Data. Med Princ Pract 2012; 21 (5): 404-428.

23. Zhou S, Zhou Z, Li C, Chen X, Yu X, Xue C, Herington A. Identification of drugs that interact with herbs in drug development. Drug Discov Today 2007; 12 (15-16): 664-673.

24. Tomlinson B, Hu M, Lee V. In vivo assessment of herb-drug interactions: Possible utility of a pharmacogenetic approach? Mol Nutrit Food Res 2008; 52 (7): 799-809.

25. Gwilt PR, Lear CL, Tempero MA, Birt DD, Grandjean AC, Ruddon RW, Nagel DL. The effect of garlic extract on human metabolism of acetaminophen. Cancer Epidemiol Biomarkers Prev 1994; 3 (2): 155-160.

26. Kolawole J, Maduenyi A. Effect of zobo drink (Hibiscus sabdariffa water extract) on the pharmacokinetics of acetaminophen in human volunteers. Eur J Drug Metab Pharmacokinet 2004; 29 (1): 25-29.

27. Anuja G, Latha P, Suja S, Shyamal S, Shine V, Sini S, Pradeep S, Shikha P, Rajasekharan S. Anti-inflammatory and analgesic properties of Drynaria quercifolia (L.) J Smith J Ethnopharmacol 2010; 132 (2): 456-460.

28. Langhendries J, Allegaert K, Van Den Anker J, Veyckemans F, Smets F. Possible effects of repeated exposure to ibuprofen and acetaminophen on the intestinal immune response in young infants 2016; 87: 90-96.

29. Langhendries J, Maton P, François-Adant A, Chantrain C, Bury F, Philippet P, Prostaglandins and the immune response at the intestinal submucosal level. A potential site for interference with the repeated use of paracetamol and ibuprofen at a young age? Arch Pediatr 2015; 22 (3): 311-319.

30. Lee W. Acetaminophen (APAP) hepatotoxicity - Isn't it time for APAP to go away? J Hepatol 2017; 67 (6): 1324-1331.

31. Ozatik FY, Teksen Y, Kadioglu E, Ozatik O, Bayat Z. Effects of hydrogen sulfide on acetaminophen-induced acute renal toxicity in rats. Int Urol Nephrol 2019; 51 (4): 745-754. 